DOI: https://doi.org/10.31073/mivg20180108-142

Available at: http://mivg.iwpim.com.ua/index.php/mivg/article/view/142

УДК 502.31:631.95

\title{
СУЧАСНИЙ СТАН ЗАБРУДНЕННЯ ЛАНДШАФТІВ ТА ОПРОМІНЕННЯ НАСЕЛЕННЯ В ГУМІДНІЙ ЗОНІ УКРӒ̈НИ
}

М.Ю. Тараріко, канд. екон. наук

Інститут агроекології і природокористування НААН. Київ. Україна;

littps://orcid.org/(0)(0)-(0)(03-1659-8919: e-mail: tararikom $a$ gmail.com

Анотація. У віддалений період після аварії на ЧАЕС в північних регіонах Житомирськой області рівень радіоактивного забруднення залииається високим як на землях сільськогосподарського призначення, так і на іниих елементах ландиафту. У результаті практично все населення зони досліджснь, окрім дітей дошкільного віку, мас рівень опромінения від 0,050 до 0,300 мЗв. Для запобігания майбутніх негативних наслідків потрібно терміново розробити систему невідкладних заходів, які, стосовно сучасного стану забруднения територій, якості його контролю та рівня радіологічного захисту населения, сприятимуть змениенню радіоактивного навантаження на людей. Усі групи населення слід забезпечити необхідними амбулаторно-поліклінічними лікарськими засобами.

Ключові слова: аварія на ЧАЕС, радіоактивне забруднення, опромінення населення, систему невідкладних заходів, радіологічний захист, медичне забезпечення

Постановка проблеми. Після аварії на Чорнобильській станції найбільше забруднення відзначалося в північних регіонах Полісся. За 30 років після аварійного періоду щільність забруднення ${ }^{91} \mathrm{Sr}$ i ${ }^{137} \mathrm{Cs}$ зменшилася майже удвічі [1]. В основному це відбулось за рахунок природного фізичного розпаду радіонуклідів. Незважаючи на зменшення активності радіонуклідів ситуація на радіоактивно забруднених територіях майже не поліпшилася, до $80 \%$ радіонуклідів зосереджено в одному шарі [2].

Основним дозо утворюючим біологічно активним радіонуклідом $\epsilon{ }^{137} \mathrm{Cs}$, основним шляхом його надходження в рослини $€$ кореневе живлення [3]. Згідно з чинним законодавством території забруднені цезієм до $1 \mathrm{Ki} /$ км $^{2}$ вважаються умовно чистими, не можливе ведення сільськогосподарського виробництва в зоні де щільність забруднення грунту цезієм більше $15 \mathrm{Ki} / \mathrm{Kм}^{2}$, стронцієм - 0,02 Ki/Км² [4].

Опромінення населення визначасться вживанням сільськогосподарської продукції, зокрема молока, що виробляється в підсобних i фермерських господарствах. Його внесок у структурі продукції становить $64 \%$, що вимагає організації ретельного контролю за вмістом радіонуклідів у сільськогосподарській продукції за різного рівня радіоактивного забруднення територій. Це дасть змогу організувати виробництво гарантовано радіоактивно безпечної продукції в зоні посиленого контролю (3-5 Ki/км ${ }^{2}$ [5] шляхом науково обгрунтованого застосування організаційних, агротехнічних і агрохімічних заходів [6-8]

(C) M.Ю. Тараріко, 2018

2018 • № 2 МЕЛПОРАЦПЯ І ВОДНЕ ГОСПОДАРСТВО
Актуальність дослідження. Хімічна меліорація радіоактивно забруднених грунтів залишається одним 3 основних заходів спрямованих на зниження радіоактивно екологічної критичності. Зокрема, поліпшення калійного живлення рослин $\epsilon$ найбільш ефективним прийомом блокування радіоцезію. Відповідно у системі удоб̆рення сільськогосподарських культур співвідношення між елементами мінерального живлення азотом, фосфором i калієм повинно становити 1:1,5:2 [9].

Значну роль у формуванні екологічно безпечного аграрного виробництва сільськогосподарської продукції на радіоактивно забруднених територіях відіграє сівозміна. Польові культури за потенційною здатністю до накопичення ${ }^{137} \mathrm{Cs}$ в значному ступеню відрізняються. Насиченням польових сівозмін культурами, що відзначаються невисокою здатністю до накопичення радіонуклідів можна до 13 разів зменшити інтенсивність міграції ${ }^{137} \mathrm{Cs}$ з грунту в рослинну біомасу i в результаті істотно зменшити дози опромінення населення [10].

Мета дослідження - оцінити довготривалий вплив традиційної органо-мінеральної системи удобрення зерно-картопляної сівозміни на радіоактивне забруднення осушуваного дерново-підзолистого грунту в порівнянні $з$ лісовими насадженнями і перелогом. Встановити рівні опромінення різних груп населення на забруднених територіях гумідної зони України за сучасної практики ведення аграрного виробництва в регіоні. 
Матеріали і методи дослідження. Експериментальні дослідження виконували в стаціонарному досліді Інституту сільського господарства Полісся НААН (с. Грозіно Коростенського району Житомирської області). Дослід було закладено в 2004 р. на осушуваному дерново-підзолистому супіщаному грунті 3 показниками родючості 0-20 см шару: гумус загальний $-0,8 \%, \mathrm{pH}_{\mathrm{KCl}}-4,7$, вміст легкогідролізованого азоту $-8,8 \mathrm{мг} / 100$ г грунту, $\mathrm{P}_{2} \mathrm{O}_{5}-8,0$, $\mathrm{K}_{2} \mathrm{O}-7,1$ мг/100 г грунту за Кірсановим.

Дослідження проводили в 4-пільній сівозміні на фоні традиційної системи удобрення а також на прилеглих елементах ландшафту: лісових насадженнях і перелозі.

Визначення питомої активності $\mathrm{Cs}^{137}$ у зразках рослин та грунту проводили шляхом радіометричних вимірів на високоефективному низькофоновому гама-спектрометрі у відповідності до ДСТУ ISO 10703-200.

Виміри випромінювання організмів людей здійснювали за допомогою приладу ЛВЛ (Лічильника Випромінювання Людини).

Результати дослідження та їх обговорення. Одним із завдань наших досліджень є визначення рівня активності радіоцезію в умовах північної частини Житомирської області на орних землях у стаціонарному досліді та на інших характерних елементах ландшафту дослідного господарства «Грозинське». Дослідження показали, що і через 30 років після Чорнобильської катастрофи рівень активності ${ }^{137} \mathrm{Cs}$ залишився високим (таб̆л. 1).

Так, активність маси підстилки в лісі дорівнювала 296 Бк/м², що значно вище ніж активність на перелозі. Однак у шарах 0-5 та 0-10 см в лісі грунт має активність істотно нижчу ніж на перелозі, що можна пояснити значним розподілом радіонуклідів після аварії на деревній та кущовій рослинності. Невисокий рівень забруднення підстилки на перелозі і навпаки дуже високий в шарі 0-10 см, можна пояснити активною мінералізацією органічної маси, що супроводжується міграцією нуклідів 3 поверхневого шару грунту вниз по профілю. Крім того значна кількість нуклідів відчужується 3 грунту з біомасою в процесі випасу корів та заготівлі кормів.

1. Активність ${ }^{137} \mathrm{Cs}$ на різних елементах ландшафту

\begin{tabular}{|c|c|c|c|c|c|c|c|c|c|c|c|c|}
\hline \multirow{3}{*}{$\begin{array}{c}\text { Шар грунту, } \\
\text { см }\end{array}$} & \multirow{2}{*}{\multicolumn{2}{|c|}{ Лic }} & \multirow{2}{*}{\multicolumn{2}{|c|}{ Переліг }} & \multicolumn{6}{|c|}{ Поля досліду } & \multirow{2}{*}{\multicolumn{2}{|c|}{$\begin{array}{c}\text { Середнє по } \\
\text { досліду }\end{array}$}} \\
\hline & & & & & \multicolumn{2}{|c|}{ тритикале } & \multicolumn{2}{|c|}{ пшениця } & \multicolumn{2}{|c|}{ картопля } & & \\
\hline & 1 & 2 & 1 & 2 & 1 & 2 & 1 & 2 & 1 & 2 & 1 & 2 \\
\hline Підстилка & 296 & 8,1 & 5,6 & 1,5 & - & - & - & - & - & - & - & - \\
\hline $0-5$ & 567 & 15,5 & 774 & 21,1 & 327 & 8,8 & 314 & 8,5 & 302 & 8,2 & 314 & 8,5 \\
\hline $5-10$ & 391 & 10,7 & 541 & 14,6 & 321 & 8,7 & 246 & 8,8 & 287 & 7,8 & 285 & 7,8 \\
\hline $10-20$ & 245 & 6,7 & 180 & 4,9 & 348 & 8,5 & 294 & 7,9 & 274 & 7,4 & 282 & 7,6 \\
\hline $0-20$ & 401 & 11,0 & 498 & 13,5 & 332 & 8,7 & 285 & 8,4 & 288 & 7,8 & 302 & 8,0 \\
\hline
\end{tabular}

l - БК/M; $2-\mathrm{Ki} / \mathrm{KM}$

Порівняння активності радіації на перелозі, лісі з полями дослідного господарства на фоні органо-мінеральної системи удобрення показало, шо в середньому по сівозміні в шарі 0-10 см вона була в 2,5 разів нижчою ніж на перелозі. Однак при цьому в шарі 10-20 см рівень активності в ріллі був значно вищим ніж в лісі і на перелозі, що пов язано з переміщенням в результаті обробітку грунту значної кількості радіонуклідів в нижню частину розпушуваного шару. Значне зменшення активності грунту в шарі 0-10 см можна пов язати з виносом радіонуклідів з урожаєм культур сівозміни [11].

Проведені дослідження свідчать, що і на віддалений період після аварії на ЧАЕС в умовах північного Полісся за високого рівня радіації практично неможливо використовувати в їжу дари лісу. При цьому відзначається зниження ефективності радіаційного контролю продукції лісового господарства протягом останнього десятиліття.

Тому іншим завданням дослідження було визначити сучасні рівні активності опромінення людей різного віку і роду діяльності які проживають в зоні північного Полісся Житомирської області. Визначення активності випромінювання у 96 дітей дошкільного віку показало, що у 68-ми невизначено опромінення, а у 26 дітей активність була в межах $0,009-0,096$ і у однісї дитини 0,136 мілізіверта (мЗв) (табл. 2)

Дослідження показали, що за умов догляду за дітьми 3 використанням чистих від радіонуклідів продуктів у основної їх кількості не визначено радіоактивного забруднення організму. У 25 -ти дітей рівень опромінення був менше 5\% від 1 мЗв (допустимого значення), і у однієї дитини був 
2. Активність опромінення дітей дошкільного віку, мЗв

\begin{tabular}{|c|c|c|c|c|c|c|}
\hline \multirow{2}{*}{$\begin{array}{c}\text { Всього } \\
\text { дітей }\end{array}$} & \multicolumn{5}{|c|}{ Активність } & \multirow{2}{*}{$\begin{array}{c}\text { Середня } \\
\text { активність } \\
\text { дітей }\end{array}$} \\
\cline { 2 - 5 } & 0,000 & $0,009-0,022$ & $0,042-0,058$ & 0,096 & 0,136 & \\
\hline 96 & 68 & 15 & 10 & 1 & 1 & 0,012 \\
\hline
\end{tabular}

3. Активність випромінювання дітей шкільного віку

\begin{tabular}{|c|c|c|c|c|c|c|c|c|}
\hline \multirow{3}{*}{ Класи } & \multirow{3}{*}{ 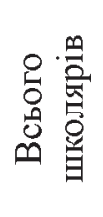 } & \multicolumn{7}{|c|}{ Активність випромінювання, мЗв } \\
\hline & & \multicolumn{2}{|c|}{$0-0,100$} & \multicolumn{2}{|c|}{$0,100-0,200$} & \multicolumn{2}{|c|}{$\geq 0,200$} & \multirow{2}{*}{\begin{tabular}{|c} 
cеред. \\
по класу \\
мЗв
\end{tabular}} \\
\hline & & $\begin{array}{l}\text { Умовний } \\
\text { контроль }\end{array}$ & \begin{tabular}{|c|} 
Кількість \\
учнів \\
\end{tabular} & $\begin{array}{l}\text { Умовний } \\
\text { контроль }\end{array}$ & $\begin{array}{c}\text { Кількість } \\
\text { учнів }\end{array}$ & $\begin{array}{l}\text { Умовний } \\
\text { контроль }\end{array}$ & $\begin{array}{c}\text { Кількість } \\
\text { учнів }\end{array}$ & \\
\hline 1 & 37 & $0,074-0,100$ & 9 & $0,100-0,200$ & 27 & 0,213 & 1 & 0,133 \\
\hline 2 & 24 & $0,049-0,100$ & 15 & - & 9 & - & - & 0,091 \\
\hline 3 & 26 & $0,064-0,100$ & 13 & - & 13 & - & - & 0,129 \\
\hline 4 & 28 & $0,070-0,100$ & 14 & - & 12 & 0,247 & 2 & 0,122 \\
\hline 5 & 36 & $0,050-0,100$ & 25 & - & 9 & 0,215 & 2 & 0,108 \\
\hline 6 & 33 & $0,054-0,100$ & 16 & - & 17 & 0,279 & 1 & 0,106 \\
\hline 7 & 33 & $0,071-0,100$ & 18 & - & 13 & 0,218 & 2 & 0,103 \\
\hline 8 & 26 & $0,023-0,100$ & 12 & - & 14 & - & - & 0,097 \\
\hline 9 & 32 & $0,050-0,100$ & 10 & - & 16 & 0,295 & 6 & 0,124 \\
\hline 10 & 6 & $0,065-0,100$ & 3 & - & 1 & 0,220 & 2 & 0,109 \\
\hline 11 & 16 & $0,050-0,100$ & 11 & - & 5 & - & - & 0,114 \\
\hline \multicolumn{8}{|c|}{ Середнє по школі } & 0,112 \\
\hline
\end{tabular}

підвищений рівень - 13,6\% від 1-го мЗв. При цьому на сьогоднішній день ніхто не може назвати гарантовано безпечну для людини і iї нащадків дозу опромінення [12].

Визначення активності радіоактивного опромінення у школярів показало, що за зміни режиму життя і раціону харчування активність випромінювання в порівнянні 3 дітьми садочків зросла 3 0,012 до 0,112 мЗв, тобто майже в 10 разів.

Особливо високою активність радіоактивного опромінення була у першокласників. Середня активність у 37-ми учнів 0,133 мЗв, що було вище ніж у середньому по школі на $18 \%$. Чіткої залежності активності випромінювання від віку школярів не визначено. Вона знаходилась в межах 9-12\% від максимально допустимого випромінювання 1 мЗв (табл. 3).

Дослідження активності випромінювання у працівників різного роду діяльності показало, що у 293 досліджуваних середня активність випромінювання дорівнювала 0,083 мЗв, що було в 7 разів нижчим ніж у дітей дошкільного віку, та у 1,3 рази меншим ніж в середньому у школярів

Незважаючи на те, що відбулось зменшення 3 часом рівня радіологічної активності екологічна ситуація на радіоактивно забруднених радіонуклідами територіях залишається важкою. Не зважаючи на це призупинено фінансування державних програм "Радіологічний захист населення та екологічне оздоровлення території, що зазнала радіоактивного забруднення".

32009 р. має місце невиправдане призупинення фінансування хімічної меліорації грунтів 3 кислою реакцією грунтового розчину. Обсяги застосування фосфорних i особливо калійних мінеральних добрив дуже низькі, в результаті система грунтово-агрохімічних заходів на радіоактивно забруднених територіях не забезпечує відповідність сільськогосподарської продукції показникам гігієнічного нормативу (ГН 6.6.1.1.-130-2006). В результаті, зокрема через недостатню інформативність населення про щільність забруднення сільськогосподарських угідь та використання їх як пасовищ i сіножатей в більшості випадків виробляється м"ясо-молочна продукція в якій питома активність радіонуклідів значно перевищує встановлені нормативи. В таких умовах населення фактично покинуте напризволяще, відбувається зростання рівня захворюваності, смертність населення становить $-16,5 \%$ (у країнах ЄC $-6,7 \%$ ) на 1000 населення, що загрожує 
спустошенням благодатного для життя регіону Полісся України.

Таке положення обумовлює термінову розробку системи невідкладних заходів які стосовно сучасного стану забруднення територій, якості його контролю та рівня радіологічного захисту населення сприятимуть зменшенню радіоактивного навантаження на людей, зокрема шляхом зниження коефіцієнтів переходу радіонуклідів у ланці грунт-рослина-тварина-людина. 3 іншого боку, для покращення демографічного стану необхідно збільшити забезпеченість території амбулаторно-поліклінічними лікарнями.

Висновки. У віддалений період після аварії на ЧАЕС в північних регіонах Житомирської області рівень радіоактивного забруднення залишається високим як на землях сільськогосподарського призначення, так і на інших елементах ландшафту. В результаті прак- тично все населення зони досліджень, окрім дітей дошкільного віку, має рівень опромінення від 0,05 до 0,300 мЗв. Рівень опромінення у дітей шкільного віку значно вищий ніж у дорослого населення. При цьому на теперішній час чітко не визначено безпечних доз опромінювання для здоров'я населення. Для отримання сільськогосподарської продукції відповідно показникам гігієнічного нормативу - ГН 6.6.1.1.-130.-2001 необхідно терміново розробити систему невідкладних заходів які стосовно сучасного стану забруднення територій, якості його контролю та рівня радіологічного захисту населення сприятимуть зменшенню радіоактивного навантаження на людей, зокрема шляхом зниження коефіцієнтів переходу радіонуклідів у ланці грунт-рослина-тварина-людина. Усі групи населення необхідно забезпечити всіма необхідними амбулаторно-поліклінічними лікарняними засобами.

\section{Бібліографія}

1. Сучасний стан мінімалізації наслідків Чорнобильської катастрофи / С.Ю. Булигін та ін. Вісник аграрної науки. 2012. № 7, С. 54-57.

2. Рекомендації по веденню сільськогосподарського виробництва в умовах радіоактивного забруднення північних районів Житомирщини постраждалих у результаті аварії на Чорнобильській AEC на період 2011 - 2016 рр. / М.М Дейсан та ін. Коростень: Друк, 2011. С. 4-5.

3. Динаміка накопичення Cs-137 у сільськогосподарських культурах / Б.С. Пристер та ін. Науковий вісник Національного аграрного університету. 2001. C. 51-56.

4. Наукові основи агропромислового виробництва в зоні Полісся і західного регіону України. Київ.: Урожай. 2004. 560 с.

5. Дутов О.І. Наукові основи формування агроекосистем на радіоактивно забруднених територіях: автореф. докт. с.-г. наук: Київ, 2013. 41 с.

6. Пристер Б.С., Хомутитин Ю.В., Перепелятникова Л.В. Оценка гарантированных коэффициентов перехода радиоактивного цезия в сельскохозяйственные культуры по агрохимическим показателям почвы. Сб. науч. тр. УНИИСХР. Проблемы сельскохозяйственной радиологии. Київ, 1991. С. 132-141.

7. Ротошнюк B.I., Ратошнюк T.M. Стан родючості та застосування агромеліоративних заходів на радіоактивно забруднених землях. Зб. Землеробство. 2004. Вип. 76. С. 57-64.

8. Витриховський П.І., Ступенко О.В. Особливості землеробства на радіоактивно забруднених землях. Вісник аграрної науки. 1997. № 5. С. 53-56.

9. Дутов О.І. Вплив калійних добрив на накопичення радіо цезію сільськогосподарських культур в різних грунтово-кліматичних умовах. Аграрна наука - селу: Зб. Подільської державної аграрно-технічної академії. Камянець-Подільський. 1999. Вип. 7. С. 66-70.

10.Дутов O.I. Сільськогосподарські культури для сівозмін в умовах радіоактивного забруднення грунту. Вісник ХДАУ (серія рослинництво). Харків. 1999. № 4. С. 164-168.

11. Дутов О.I. Особливості кормовиробництва в умовах радіоактивного забруднення грунту. Науково - технічний бюлетень Інституту землеробства і біології тварин. Вип. 1 (2). Львів, 1999. C. $49-52$.

12.Краснов В.П., Курбет Т.В., Давидова І.В., Ландін В.П. Збалансоване природокористування. № 3. 2016. С. 195-200. 


\section{References}

1. Bulygin, S.Yu. (2012). Suchasnyy stan minimalizacii naslidkiv Chornobylskoi catastrophy |The current state of minimizing the consequences of the Chernobyl disaster |. Visnyk agrarnoi nauky, 7, 54-57. [in Ukrainian].

2. Deisan, M. M. (2011). Rekomendatsii po vedenniu silskohospodarskoho vyrobnytstva $v$ umovakh radioaktyvnoho zabrudnennia Pivnichnykh raioniv Zhytomyrshchyny postrazhdalykh u rezultati avarii na Chornobylskii AES na period 2011-2016 rr |Recommendations for the management of agricultural production in conditions of radioactive contamination of the Northern regions of Zhytomyr region affected by the Chernobyl accident for the period of 2011-2016]. Korosten: Druk. 4-5. [in Ukrainian].

3. Pryster. B.S. (2004). Dynamika nakopychennia Cs-137 u silskohospodarskykh kulturakh [The dynamics of accumulation of Cs-137 in agricultural crops]. Naukovyi visnyk Natsionalnoho ahrarnoho universytetu. 51-56. [in Ukrainian].

4. Naukovi osnovy ahropromyslovoho vyrobnytstva v zoni Polissia i zakhidnoho rehionu Ukrainy [Scientific basis of agricultural production in the zone of Polissya and the Western region of Ukraine] (2004). Kyiv: Urozhai. (In Ukr.).

5. Dutov, O.I. (2013). Naukovi osnovy formuvannia ahroekosystem na radioaktyvno zabrudnenykh terytoriiakh [Scientific bases of formation of agro-ecosystems on radioactively contaminated territory]. Extended abstract of Doctor's thesis. Kyiv. [in Ukrainian].

6. Pryster, B.S., Khomutytyn, Yu.V., \& Perepeliatnykova, L.V. (1991). Otsenka harantyrovannykh koeffytsyentov perekhoda radyoaktyvnoho tsezyia $\mathrm{v}$ selskokhoziaistvennye kultury po ahrokhymycheskym pokazateliam pochvy [Estimation of guaranteed coefficients of transition of radioactive cesium to agricultural crops by agrochemical indicators of soil]. Kyiv: Sb. nauch. tr. UNYYSKhR, Problemy selskokhoziaistvennoi radyolohyy, 132-141. [in Russian].

7. Ratoshniuk, V.I., \& Ratoshniuk, T.M. (2004). Stan rodyuchosti tazastosuvannya ahromelioratyvnykh zakhodiv na radioaktyvno zabrudnenykh zemlyakh [The state of fertility and the use of agromelioration measures on radioactive contaminated lands]. Zb. Zemlerobstvo, 76, 57-64. [in Ukrainian].

8. Vytrykhovskyi, P.I., \& Stupenko, O.V. (1997). Osoblyvosti zemlerobstva na radioaktyvno zabrudnenykh zemliakh [Features of agriculture on radioactive contaminated lands]. Visnyk ahrarnoi nauky, 5, 53-56. [in Ukrainian].

9. Dutov, O.I. (1999). Vplyv kalyinykh dobrrv na nakopychennia radio tseziiu silskohospodarskykh kultur $\mathrm{v}$ riznykh hruntovo-klimatychnykh umovakh [Influence of potassium fertilizers on the accumulation of radiocesium crops in various soil-climatic conditions]. Ahrarna nauka - selu: $\mathrm{Zb}$. Podilskoi derzhavnoi ahrarno-tekhnichnoi akademii, Kamianets-Podilskyi, 7, 66-70. [in Ukrainian].

10.Dutov. O.I. (1999). Silskohospodarski kultury dlia sivozmin v umovakh radioaktyvnoho zabrudnennya gruntu [Agricultural crops for crop rotations in conditions of radioactive contamination of the soil]. Visnyk KhDAU (seriya roslynnytstvo), Kharkiv, 4, 164-168. [in Ukrainian].

11. Dutov. O.I. (1999). Osoblyvosti kormovyrobnytstva v umovakh radioaktyvnoho zabrudnennia gruntu [Features of fodder production in conditions of radioactive contamination of the soil]. Naukovotekhnichnyi biuleten Instytutu zemlerobstva i biolohii tvaryn, 1 (2), Lviv. 49-52. [in Ukrainian].

12.Krasnov, V.P., Kurbet, T.V., Davydova, I.V., \& Landin. V.P. (2016). Zbalansovane pryrodokorystuvannya [Balanced natural resources management]. 3, 195-200. [in Ukrainian].

\section{Современное состояние загрязнения ландшафтов и облучения населения в гумидной зоне Украины}

Аннотация. В отдаленный период после аварии на ЧАЭС в северных регионах Житомирской области уровень радиоактивного загрязнения остается высоким как на землях сельскохозяйственного назначения, так и на других элементах ландиафта. В результате практически все население зоны исследований, кроме детей доикольного возраста, имеет уровень облучения oт 0.050 до 0.300 м 3 в. Для предотвращения будуиих негативных последствий нужно срочно разработать систему неотложных мер. в отночении современного состояния загрязнения территорий, качества его контроля и уровня радиологической защиты населения, способствовать уменьиению радиоактивной нагрузки на людей. Все группь населения следует обеспечить необходимыми амбулаторно-поликлиническими лекарственными средствами.

Ключевые слова: авария на ЧАЭС, радиоактивное загрязнение, облучение населения, система неотложных мер, радиологическая защита. медиинское обеспечение. 
M.Yu. Tarariko

The current state of contamination of landscapes and irradiation of the population in the humid zone of Ukraine

Annotation. In the remote period after the Chornobyl (Chornobyl Nuclear Power Plant) accident in the northern regions of Zhytomyr region, the level of radioactive contamination remains high both on agricultural lands and on other elements of the landscape. As a result, virtually all population of the research zone, except for pre-school children, has an irradiation level of 0.050 to $0.300 \mathrm{mSv}$. In order to prevent future negative consequences. it is urgently needed to develop a system of urgent measures that, in relation to the current state of pollution of the territories, the quality of its control and the level of radiological protection of the population, will contribute to reducing the radioactive burden on people. All population groups should be provided with the necessary ambulatory-polyclinic drugs. Key words: accident at Chornobyl (ChNPP), radioactive contamination, population irradiation. system of urgent measures, radiological protection, medical support. 